Phytologia (November 1993) 75(5):402-403.

\title{
AGERATINA ACEVEDOANA (ASTERACEAE, EUPATORIEAE), A NEW SPECIES FROM NORTHERN DURANGO
}

\author{
Billie L. Turner \\ Department of Botany, University of Texas, Austin, Texas 78713 U.S.A.

\section{ABSTRACT} \\ A new species of Ageratina, A. acevedoana B.L. Turner, is de- \\ scribed from northern Durango, México. It belongs to the subgenus \\ Ageratina and relates to a group of glandular-pubescent taxa centering \\ about $A$. parryana.
}

KEY WORDS: Asteraceae, Eupatorieae, Ageratina, México

Routine identification of Mexican Asteraceae has revealed the following novelty.

Ageratina acevedoana B.L. Turner, sp. nov. TYPE: MEXICO. Durango: $10 \mathrm{~km}$ de Canelas, por la camino a Santiago Papasquiaro, "Laderas sombreadas en bosque alto de pino-encino", $1060 \mathrm{~m}, S$. Acevedo y $D$. Bayona 190 (HOLOTYPE: TEX!; Isotype: CIIDIR).

Ageratinae parryanae (Espinosa) B.L. Turner similis sed foliis midcaulinis minoribus late ovatis vel deltoideis (vs. cordatis), capitulis congestioribus $(3-4 \mathrm{~cm}$ latis vs. $10-15 \mathrm{~cm})$, et vestimento trichomatibus glandulosis $0.5-1.0 \mathrm{~mm}$ altis (vs. $0.2-0.4 \mathrm{~mm}$ ).

Perennial herbs $30-50 \mathrm{~cm}$ high. Stems densely glandular-pilose, the hairs 0.6-1.3 mm long. Leaves opposite throughout, gradually reduced upwards, those at midstem $10-15 \mathrm{~cm}$ long, $4-5 \mathrm{~cm}$ wide; petioles $4-6 \mathrm{~cm}$ long, pubescent like the stem; blades broadly ovate to deltoid, 3-5 nervate from the base, glandular-pilose, more so above, the margins coarsely crenulodentate. Heads 5-20 in terminal corymbs, the ultimate peduncles glandular-pilose, mostly 3-10 $\mathrm{mm}$ long. Involucres turbocampanulate, 5-6 mm high, 6-10 mm wide (pressed), 
glandular-pubescent, the bracts linear-lanceolate with acute apices. Receptacle convex, epaleate, glabrous. Florets numerous $(80+)$, the corollas 3.5-4.0 $\mathrm{mm}$ long; tubes ca. $1.5 \mathrm{~mm}$ long, glabrous; throats abruptly ampliate, ca. 2 $\mathrm{mm}$ long, the lobes mostly with at least a few multiseptate trichomes. Achenes fusiform, ca. $1.6 \mathrm{~mm}$ long, sparsely hispidulous, the pappus of numerous readily deciduous bristles ca. $3 \mathrm{~mm}$ long.

ADDITIONAL SPECIMEN EXAMINED: MEXICO. Durango: Same locality as type, $2060 \mathrm{~m}, 10 \mathrm{Mar} 1987, S$. Acevedo 199 (TEX).

Ageratina acevedoana belongs to the subgenus Ageratina where it relates to a number of glandular-pubescent species of western México including $A$. gentryana B.L. Turner, A. warnockii B.L. Turner, and A. parryana (Espinosa) B.L. Turner. It appears most closely related to the latter, which occurs in the states of Michoacán, México, and Guerrero, in having similar long-petiolate leaves with a similar glandular-pubescent vestiture. It differs in having smaller ovate to subcordate leaves and much-reduced capitulescences.

It is a pleasure to name this taxon for its principal collector Ms. S. Acevedo, one of the more active collectors of Durango and associated areas.

\section{ACKNOWLEDGMENTS}

I am grateful to Guy Nesom for the Latin diagnosis, and to him and T.P. Ramamoorthy for reviewing the manuscript. 


\section{$2 \mathrm{BHL}$ Biodiversity Heritage Library}

Turner, B. L. 1993. "Ageratina acevedoana (Asteraceae, Eupatorieae), a new species from northern Durango." Phytologia 75, 402-403.

https://doi.org/10.5962/bhl.part.20866.

View This Item Online: $\underline{\text { https://www.biodiversitylibrary.org/item/47148 }}$

DOI: https://doi.org/10.5962/bhl.part.20866

Permalink: https://www.biodiversitylibrary.org/partpdf/20866

\section{Holding Institution}

New York Botanical Garden, LuEsther T. Mertz Library

\section{Sponsored by}

The LuEsther T Mertz Library, the New York Botanical Garden

\section{Copyright \& Reuse}

Copyright Status: In copyright. Digitized with the permission of the rights holder.

Rights Holder: Phytologia

License: http://creativecommons.org/licenses/by-nc-sa/3.0/

Rights: https://biodiversitylibrary.org/permissions

This document was created from content at the Biodiversity Heritage Library, the world's largest open access digital library for biodiversity literature and archives. Visit BHL at https://www.biodiversitylibrary.org. 